\title{
Efectele SARS-CoV-2 în sarcină și la nou-născuți - un nou agent TORCH?
}

\author{
Andreia Florina Niță1', Sabina Cornelia Manolescu', \\ Mircea Ioan Popa ${ }^{1,2}$, Loredana Gabriela Popa ${ }^{1,3}$ \\ ${ }^{1}$ Universitatea de Medicină și Farmacie „Carol Davila“, București, România \\ 2Institutul Național de Cercetare-Dezvoltare Medico-Militară „Cantacuzino“, București, România \\ ${ }^{3}$ Spitalul Clinic Colentina, București, România
}

\begin{abstract}
REZUMAT
Obiective. Acest studiu și-a propus să efectueze o revizuire sistematică a literaturii existente pentru a evalua efectele COVID-19 la femeile însărcinate și la nou-născuții acestora, estimând, în același timp, posibilitatea transmiterii verticale.

Materiale şi metode. Am efectuat o cercetare sistematică a literaturii folosind Pubmed și Google Scholar, acoperind perioada decembrie 2019-noiembrie 2020. Revizuirea a fost efectuată în conformitate cu ghidurile PRISMA.

Rezultate. Am inclus 16 studii - recenzii sistematice și metaanalize publicate între mai 2020 și noiembrie 2020 - care s-au concentrat pe rezultatele perinatale ale femeilor însărcinate cu COVID-19 și 7 prezentări de cazuri ale nou-născuților cu transmitere verticală a COVID-19. În general, rata cazurilor de COVID-19 la nou-născuții din mame COVID-19 pozitive a fost de $3 \%$ cu CI 95\% [1,86, 4,24]). Rata nașterii premature a fost de 16,4\%, cu CI 95\% [10,5, 22,3], iar rata mortalității și a deceselor fetale a fost de 1,4\% (11 studii, 0 până la $4,8 \%$ ). Dintre cei 7 nou-născuți cu transmitere verticală dovedită, majoritatea s-au născut prematuri, cu greutate bună la naștere și scor APGAR, iar manifestările clinice au fost heterogene; 4 au dezvoltat simptome severe. Evoluțiile atât pentru mamă, cât și pentru nou-născuţi au fost bune în $85 \%$ dintre cazuri. Concluzii. În ceea ce privește rata prematurității și rata mortalității la femeile cu COVID-19, rezultatul este similar cu populația generală. Transmiterea verticală este posibilă și pare să aibă loc în aproximativ $3 \%$ dintre cazuri. Prognosticul matern și perinatal este favorabil, iar prezentarea clinică a transmiterii în uter a SARS-CoV-2 la nou-născuți este heterogenă.
\end{abstract}

Cuvinte cheie: COVID-19, transmisie verticală, nou-născuţi, infecţie congenitală

\section{INTRODUCERE}

Pe 11 martie 2020, noua infecţie cu coronavirus a fost declarată pandemie globală de Organizaţia Mondială a Sănătăţii (OMS). Pe 15 noiembrie 2020, au fost raportate de către OMS 53,7 milioane de cazuri confirmate şi 1,3 milioane de decese (1).

La nivel mondial, există aproximativ 210 milioane de femei însărcinate anual, cu un număr estimat de 170 de milioane de naşteri (2).

Este bine cunoscut faptul că modificările fiziologice care apar în timpul sarcinii fac ca femeia să fie vulnerabilă la infecții severe, iar femeile însărcinate au fost considerate un grup delicat în timpul noii pandemii, deoarece puţine informaţii au fost disponibile, în special la începutul pandemiei.

Datele privind efectele infecţiei cu SARS-CoV-2 asupra sarcinii sunt rare, limitate în principal la prezentări de cazuri, serii de cazuri sau recenzii. Ghidurile de management clinic sunt modificate continuu şi orice informaţie este valoroasă. Ritmul publicării este rapid, iar informaţiile vin din orice ţară, de aceea este de înţeles că datele nu sunt sistematizate, ceea ce face ca interpretarea şi punerea la îndoială a fiabilităţii informaţiei disponibile în literatură să fie dificile. 


\section{OBIECTIV}

Am efectuat o revizuire sistematică a articolelor publicate disponibile despre rezultatele SARS-CoV-2 în timpul sarcinii, cu accent pe efectele neonatale şi pe transmiterea verticală.

\section{METODE}

\section{Strategia de căutare și selecție}

Am efectuat o cercetare sistematică a literaturii folosind Pubmed şi Google Scholar, acoperind perioada decembrie 2019-20 noiembrie 2020. Am folosit următorii termeni pentru căutare: COVID-19, sarcină, congenital, perinatal, nou-născuţi/neonatal, transmisie verticală. Titlurile şi rezumatele au fost revizuite de autori pentru a determina relevanţa lor. Criteriile de includere au fost: articole scrise în limba engleză, infecţia cu COVID-19 confirmată de laborator, fie la femeia însărcinată, fie la nou-născuţi, informaţii despre efectele materne şi neonatale. Evaluarea calităţii articolelor incluse nu a fost efectuată pentru a nu limita datele disponibile chiar prea rare în literatura de specialitate. Criteriile de excludere au inclus: cazuri neconfirmate de COVID-19, efecte materne sau neonatale nedeclarate. Revizuirile sistematice găsite în literatură au inclus deja rapoartele de caz şi seriile de cazuri disponibile, prin urmare nu am analizat individual fiecare serie de cazuri sau prezentare de caz, ci am reunit toate datele. În ceea ce priveşte transmisia verticală, am adunat toate prezentările de caz disponibile şi le-am analizat.

\section{Extragerea și sinteza datelor}

Revizuirea a fost efectuată în conformitate cu liniile directoare PRISMA. Căutarea în literatură a returnat 474 de lucrări care au fost examinate iniţial după titlu şi rezumat, urmate de preluarea textului complet, după caz. Duplicatele au fost identificate printr-un screening manual independent. Deoarece studiile sunt foarte heterogene, analiza statistică nu a fost încercată, dar autorii au ales o abordare narativă pentru raportarea fiabilă a datelor disponibile.

Informaţiile clinice relevante despre nou-născuţi şi femeile însărcinate au fost extrase din studiile incluse şi au fost rezumate în tabele separate. Rezultatele sarcinilor la femeile SARS-CoV-2 pozitive au fost extrase. Mama a fost considerată a avea infecţie cu COVID-19 dacă RT-PCR din exsudat nazofaringian a fost pozitiv. Nou-născutul a fost considerat a avea infecţie COVID-19 dacă analiza RT-PCR din exsudat nazofaringian/orofaringian al sugarului, sânge/cordon ombilical sau lichid amniotic sau biopsie placentară a fost pozitivă.

\section{REZULTATE}

\section{Rata infecției cu COVID-19 la nou-născuții femeilor COVID-19 pozitive}

Am inclus 16 studii - recenzii sistematice şi metaanalize publicate în perioada mai 2020-noiembrie 2020 - care s-au concentrat pe rezultatele perinatale ale femeilor însărcinate cu COVID-19. Numărul de studii analizate de fiecare dintre analizele sistematice pe care le-am inclus a variat de la 11 la 77 . Numărul femeilor însărcinate incluse în studii a fost cuprins între 68 şi 11.432, cu un număr total de 27.546 (două studii nu au raportat numărul de femei însărcinate incluse, deoarece scopul a fost determinarea efectelor asupra nou-născutului, nu asupra gravidei).

Numărul total de nou-născuţi testaţi pentru COVID-19 a fost de 5906; conform fiecărui studiu analizat, acesta a variat între 46 şi 1992. Numărul total de nou-născuţi COVID-19 pozitivi a fost de 209. În general, rata cazurilor de COVID-19 la nou-născuţii de mame COVID-19 pozitive a fost de $3 \%$ cu IC $95 \%$ $[1,86,4,24])$; acest lucru a fost raportat de 15 studii, iar ratele au fost cuprinse între 0 şi 7\%. Datele sunt rezumate în tabelul 1.

\section{Efectele COVID-19 asupra sarcinii}

Datele privind vârsta gestaţională la naştere au fost raportate de 9 din cele 16 studii incluse. Rata generală a naşterii premature a fost de $16,4 \%$, cu IC $95 \%[10,5,22,3]$.

La femeile însărcinate care au fost testate pozitiv pentru COVID-19, rata globală a naşterilor mortale şi a deceselor fetale a fost de 1,4\% (11 studii, 0 până la $4,8 \%)$.

Rata generală a deceselor neonatale a fost de $0,5 \%$ (12 studii, 0-2\%).

Datele privind decesele materne au fost raportate doar de 2 studii - rata $0,4 \%$ şi $4,1 \%$.

Toate datele sunt detaliate în Tabelul 1.

\section{Caracteristicile nou-născuților cu transmitere verticală a COVID-19}

Am inclus în revizuirea noastră 7 prezentări de caz ale nou-născuţilor cu transmitere verticală a 


\begin{tabular}{|c|c|c|c|c|c|c|c|c|c|c|c|}
\hline 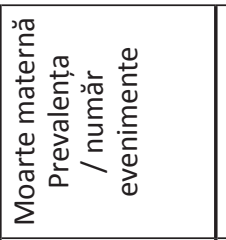 & 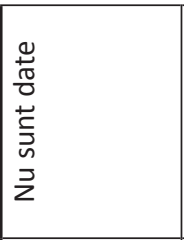 & 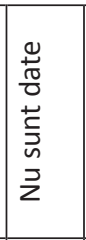 & 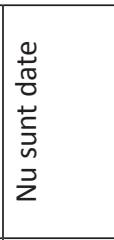 & 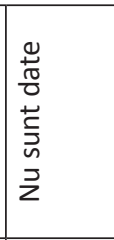 & 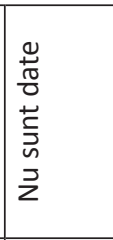 & 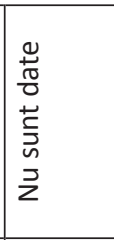 & 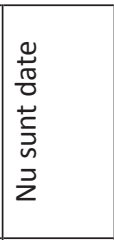 & 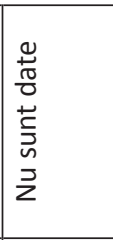 & 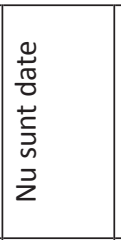 & 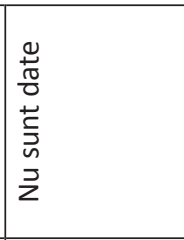 & 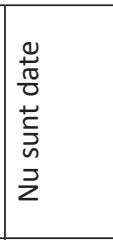 \\
\hline 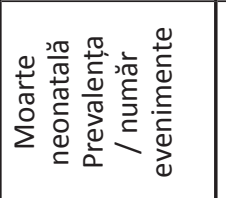 & 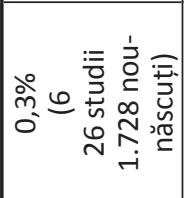 & 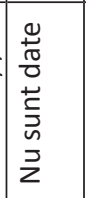 & $\begin{array}{l}\bar{\Xi} \\
\stackrel{0}{\circ} \\
\dot{\sigma} \\
0\end{array}$ & $\begin{array}{l}\bar{m} \\
\stackrel{0}{0} \\
\hat{0}\end{array}$ & 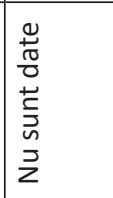 & 0 & 0 & 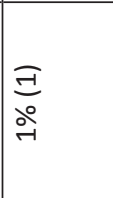 & $\begin{array}{l}\bar{\Xi} \\
\dot{0} \\
\dot{\partial} \\
0\end{array}$ & $\begin{array}{l}\bar{\Xi} \\
\stackrel{\theta}{0} \\
\tilde{o} \\
0\end{array}$ & 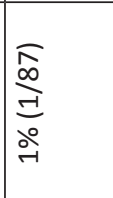 \\
\hline 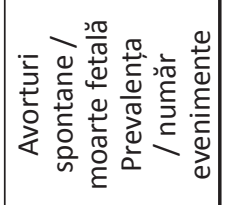 & 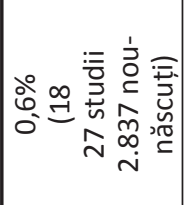 & 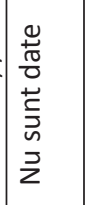 & 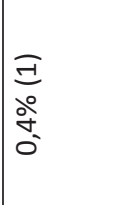 & 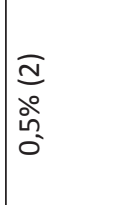 & 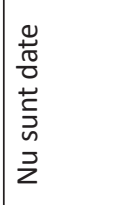 & 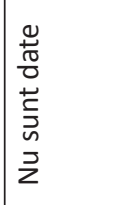 & 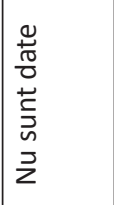 & $\begin{array}{l}\frac{\pi}{0} \\
\alpha \\
0 \\
\infty \\
\dot{\sigma}\end{array}$ & 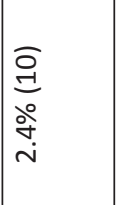 & 0 & $\begin{array}{l}\frac{\pi}{\infty} \\
\stackrel{\infty}{1} \\
\stackrel{\circ}{\circ}\end{array}$ \\
\hline 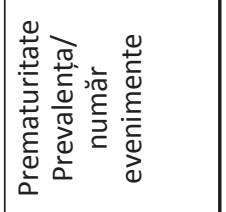 & 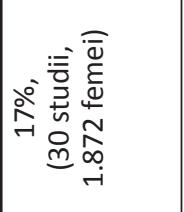 & 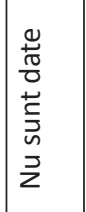 & 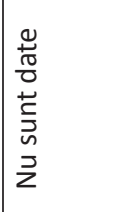 & 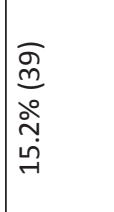 & 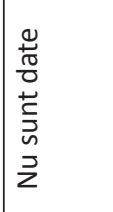 & 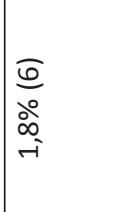 & 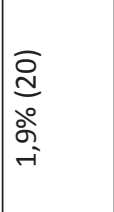 & 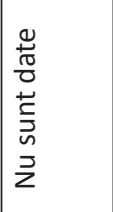 & 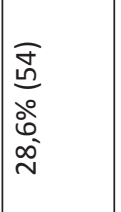 & 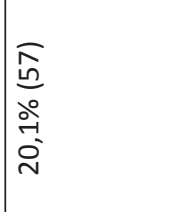 & 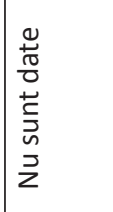 \\
\hline 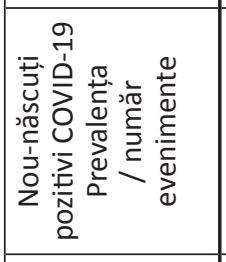 & 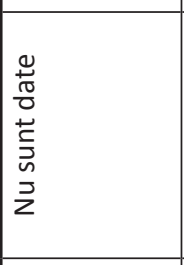 & 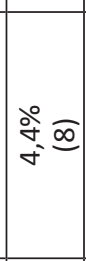 & 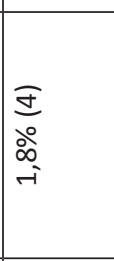 & 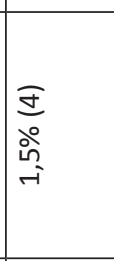 & $\frac{\pi}{\frac{\pi}{0}}$ & $\begin{array}{l}\overline{\mathfrak{d}} \\
\stackrel{d}{\grave{n}} \\
\frac{1}{n}\end{array}$ & 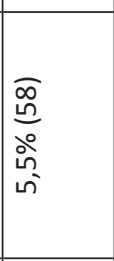 & 0 & $\begin{array}{l}\frac{n}{n} \\
\dot{\circ} \\
\stackrel{-}{-} \\
-i\end{array}$ & 0 & $\frac{\Xi}{\partial}$ \\
\hline 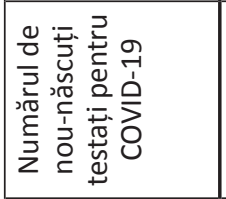 & 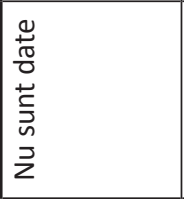 & $\underset{7}{\stackrel{9}{7}}$ & $\vec{\sim}$ & $\stackrel{\stackrel{0}{N}}{N}$ & $\vec{N}$ & $\underset{\sim}{\stackrel{0}{m}}$ & $\mid \begin{array}{l}\infty \\
\text { Oे } \\
\text { i }\end{array}$ & $\mathscr{q}$ & $\underset{m}{\infty}$ & 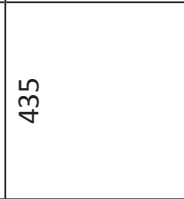 & $\stackrel{n}{N}$ \\
\hline 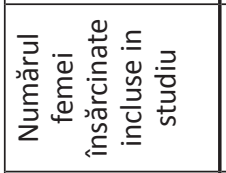 & 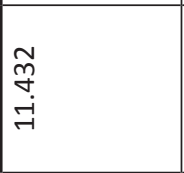 & 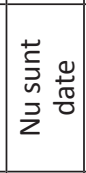 & 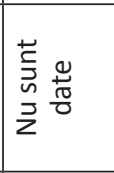 & 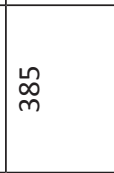 & $\infty$ & $\underset{m}{\infty}$ & 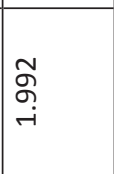 & 弚 & $\begin{array}{l}\tilde{\tilde{\sigma}} \\
\tilde{\sigma}\end{array}$ & $\mid \begin{array}{l}\infty \\
\end{array}$ & 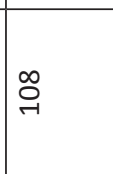 \\
\hline 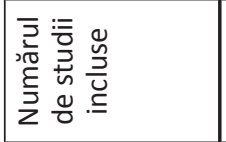 & $\curvearrowright$ & $\stackrel{m}{r}$ & 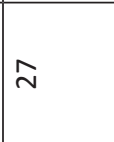 & $m$ & $\underset{7}{\sim}$ & ஜ) & 年 & $\exists$ & $\exists$ & $\stackrel{m}{r}$ & $\underset{\sim}{\infty}$ \\
\hline 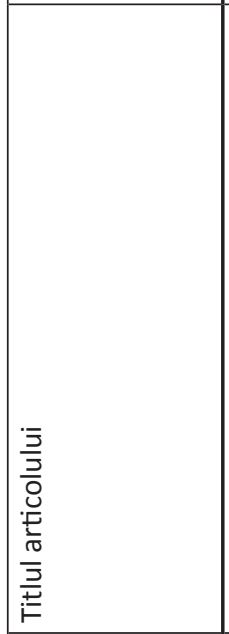 & 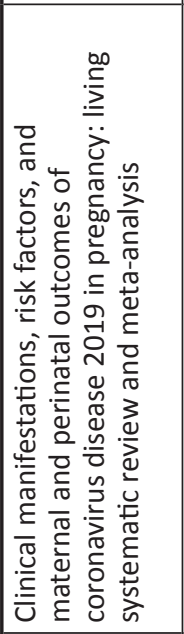 & 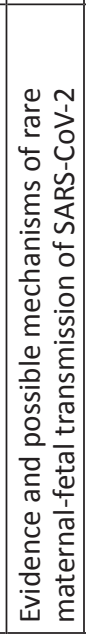 & 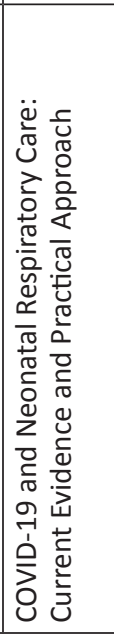 & 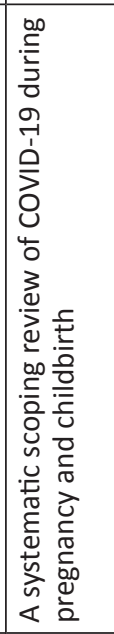 & 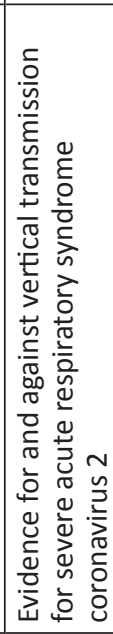 & 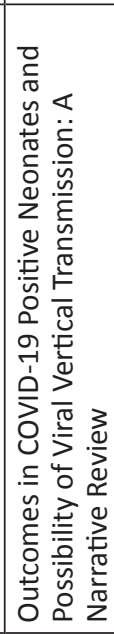 & 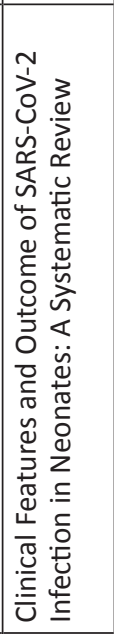 & 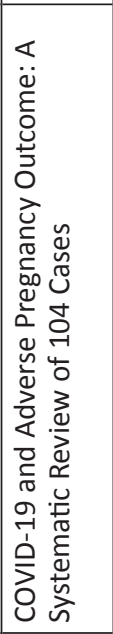 & 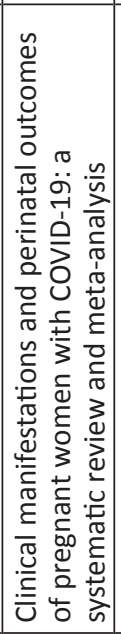 & 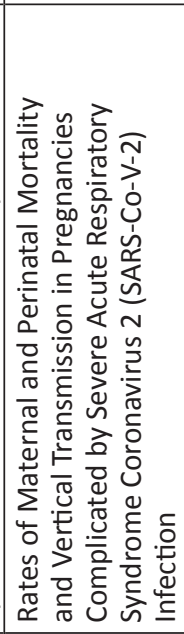 & 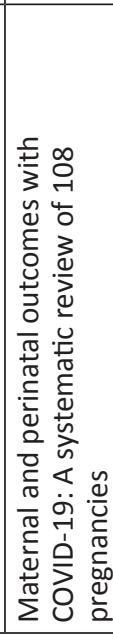 \\
\hline 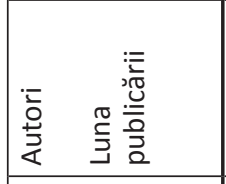 & 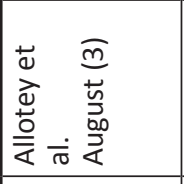 & 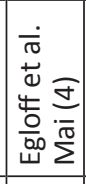 & 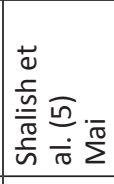 & 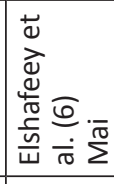 & 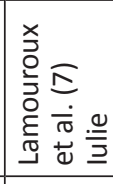 & 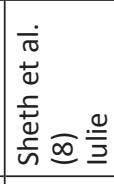 & 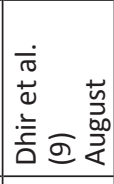 & 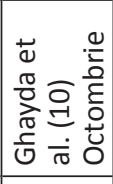 & 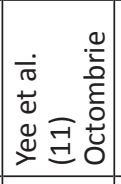 & 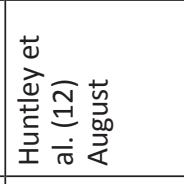 & 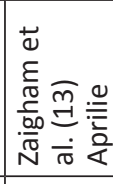 \\
\hline & H & $\sim$ & $m$ & o & in & 0 & $r$ & $\infty$ & $\sigma$ & 우 & $\exists$ \\
\hline
\end{tabular}




\begin{tabular}{|c|c|c|c|c|c|}
\hline 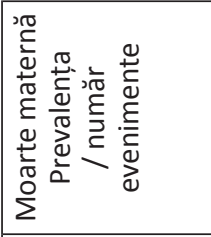 & 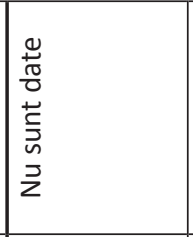 & $\begin{array}{l}\frac{\pi}{n} \\
o \\
\vdots \\
0 \\
0\end{array}$ & 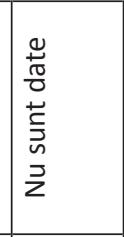 & 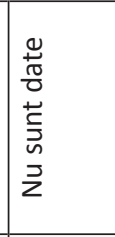 & 送 \\
\hline 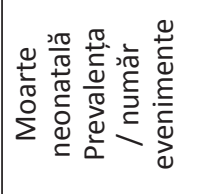 & $\begin{array}{l}\frac{0}{0} \\
\dot{0} \\
\dot{0} \\
0\end{array}$ & $\begin{array}{l}\frac{0}{m} \\
\text { òे } \\
\text { ò }\end{array}$ & 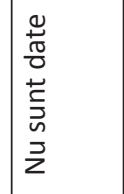 & 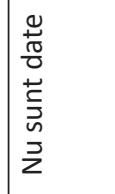 & $\begin{array}{l}\text { in } \\
\stackrel{n}{N} \\
\text { in } \\
\stackrel{N}{0}\end{array}$ \\
\hline 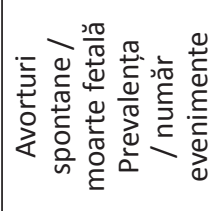 & 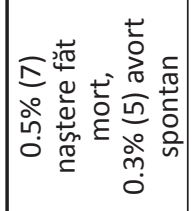 & 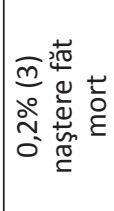 & 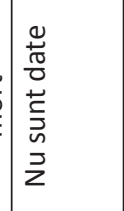 & 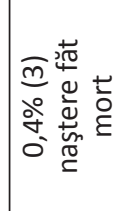 & 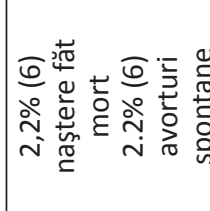 \\
\hline 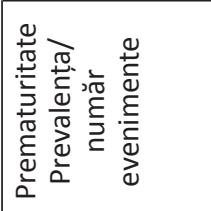 & 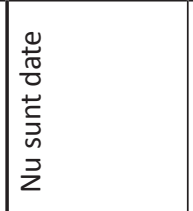 & 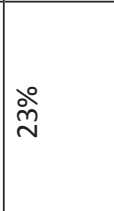 & 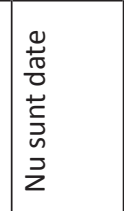 & 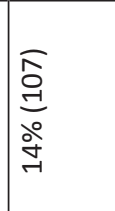 & 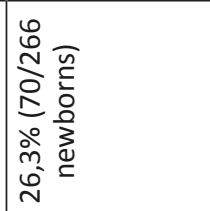 \\
\hline 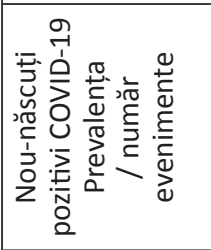 & 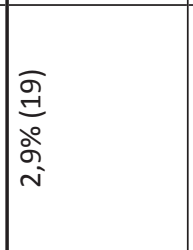 & 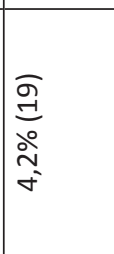 & 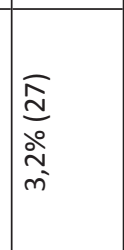 & 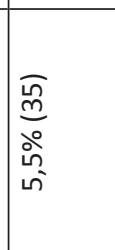 & 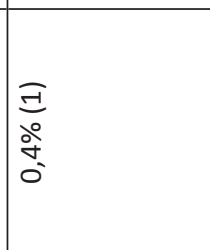 \\
\hline 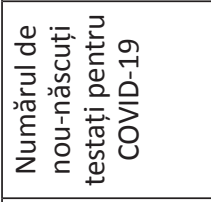 & 虽 & F & $\begin{array}{l}\infty \\
\mathscr{n}\end{array}$ & శ్రి & 总 \\
\hline 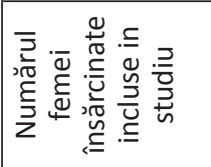 & 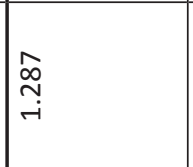 & $\begin{array}{l}\stackrel{8}{\rightarrow} \\
\text { - }\end{array}$ & 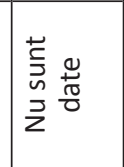 & $\stackrel{\infty}{\stackrel{\infty}{N}}$ & $\begin{array}{l}\infty \\
m \\
m\end{array}$ \\
\hline 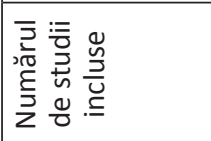 & 8 & $\stackrel{\text { I }}{ }$ & 8 & 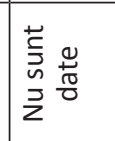 & 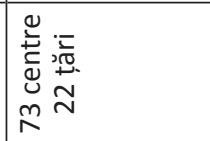 \\
\hline \begin{tabular}{|l}
$\frac{3}{5}$ \\
$\frac{0}{0}$ \\
$\frac{5}{5}$ \\
$\frac{\pi}{3}$ \\
\end{tabular} & 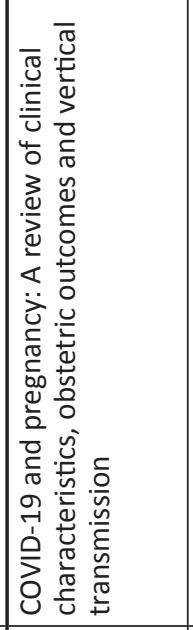 & 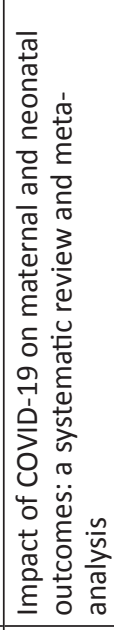 & 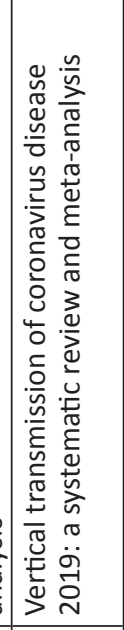 & 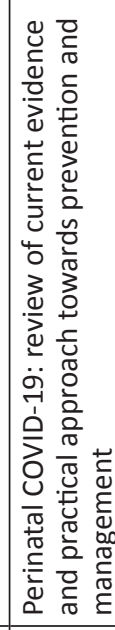 & 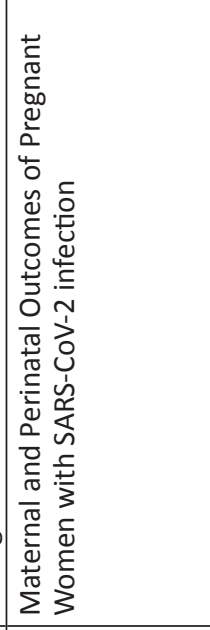 \\
\hline 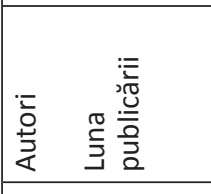 & 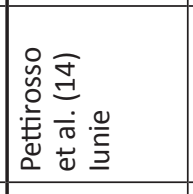 & 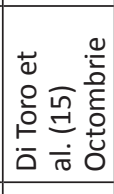 & 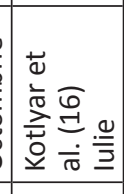 & 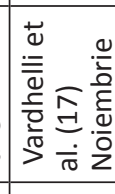 & 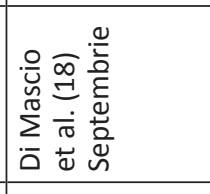 \\
\hline & $\approx$ & $\eta$ & $\nexists$ & $\bumpeq$ & $\underset{7}{1}$ \\
\hline
\end{tabular}


COVID-19. În total, 7 nou-născuţi cu dovezi ale transmiterii transplacentare au fost raportaţi în perioada martie - septembrie 2020 în: China, Iran, Canada, Franţa, Germania, Arabia Saudită, SUA. Dostribuţia pe sexe este de 5:2 femei la bărbaţi nou-născuţi. Majoritatea nou-născuţilor $\mathrm{n}=5 / 7$ s-au născut prin cezariană. Naşterea prematură a avut loc în $n=6 / 7$ cazuri, la o vârstă gestaţională de 32 săptămâni până la 35 săptămâni, cu o mediană de 34 săptămâni. Greutatea la naştere a fost adecvată pentru vârsta gestaţională pentru toţi nou-născuţii, variind între $2.350 \mathrm{~g}$ şi $3.280 \mathrm{~g}$. Scorul APGAR a fost în categoria superioară pentru şase nou-născuţi, respectiv între 7 şi 9 la 1 minut şi 8 şi 10 la 5 minute. Un copil a primit un scor APGAR de 4 la 1 minut urmat de 2 la 5 minute. Majoritatea nou-născuţilor ( $\mathrm{n}=6$ din 7) au fost admişi la unitatea de terapie intensivă neonatală (TINN) la scurt timp după naştere, pentru suport respirator $(\mathrm{n}=1)$, resuscitare neonatală $(\mathrm{n}=1)$, simptome encefalitice $(\mathrm{n}=1)$, hipoglicemiant episoade $(n=1)$, gestionarea prematurităţii $(\mathrm{n}=2)$.

Toate datele sunt detaliate în Tabelul 2.

Simptomele nou-născuţilor cu transmitere verticală COVID-19 sunt destul de heterogene. Trei nounăscuţi nu au avut niciun simptom/sau simptome uşoare, după cum urmează: prezentare asimptomatică $(n=1)$, febră ca singur simptom $(n=1)$ şi febră plus simptome respiratorii minore $(\mathrm{n}=1)$. Patru nounăscuţi au avut o prezentare severă: unul a prezentat suferinţă respiratorie severă cu hipertensiune pulmonară persistentă, unul a avut hipoglicemie persistentă, hipotermie şi dificultăţi de hrănire şi doi simptome neurologice - într-un caz semnele encefalitice au început la 24 de ore de viaţă, urmate de suferinţă respiratorie la 80 de ore de viaţă, în timp ce în celălalt caz raportat, semnele neurologice (iritabilitate, dificultăţi alimentare, hipertonie axială, opistotonus) au început la 72 de ore de viaţă, iar RMN a arătat glioză bilaterală a substanţei albe profunde periventriculare şi subcorticale.

În ceea ce priveşte diagnosticarea transmiterii verticale a COVID-19, patru dintre cazuri au prezentat PCR pozitiv pentru COVID-19 din lichid amniotic, placentă şi exsudat nazofaringian la 24 de ore, un caz a avut exsudat placentar şi exsudat nazofaringian pozitiv; într-un caz exsudatul nazofaringian şi rectal au fost pozitive. Un caz a avut în mod repetat rezultat IgM COVID-19 exsudat nazofaringian negativ, dar pozitiv la 2 ore de viaţă şi persistent ulterior; PCR de placentă /lichid amniotic nu au fost efectuate.
Prognosticul neonatal a fost bun în majoritatea cazurilor, şase nou-născuţi fiind externaţi în mai puţin de o lună. Un nou-născut care suferea de sindrom de detresă respiratorie, insuficienţă cardiorespiratorie, hipertensiune pulmonară persistentă a decedat în ziua 11.

Analizând caracteristicile mamelor cazurilor raportate, am constatat că intervalul de vârstă a fost cuprins între 22 şi 40 de ani, cu trei femei cu vârsta $<30$ de ani, trei femei cu vârsta $>35$ de ani şi într-un caz vârsta nu a fost raportată. Patru mame au prezentat simptome minore: febră, simptome respiratorii uşoare, împreună cu pierderea mirosului şi a gustului într-unul dintre cazuri şi diaree în alt caz. Trei dintre femeile însărcinate au prezentat suferinţă respiratorie şi febră şi, printre acestea, un caz a asociat sângerări vaginale. Şase mame au avut o evoluţie bună şi au fost externate împreună cu nou-născuţii lor. Una dintre femeile care prezentau suferinţă respiratorie a decedat în ziua 19.

\section{DISCUȚII}

Analiza noastră cuprinzătoare a studiilor care descriu efectele infecţiei cu SARS-CoV-2 în timpul sarcinii a arătat că incidenţa transmiterii verticale a COVID-19 a fost de $3 \%$.

Rezultatele obţinute au fost similare cu populaţia generală. Rata prematură la femeile însărcinate cu infecţie COVID-19 a fost de 16,4\%, comparabilă cu incidenţa globală de 5-18\% în populaţia generală gravidă (26).

Rata mortalităţilor a fost de $1,4 \%$, mai mică decât cea din populaţia generală - 1,8\%; majoritatea cazurilor de deces neonatal sunt raportate în ţările cu venituri mici, în timp ce studiile analizate au provenit în principal din ţările dezvoltate (26). Cu toate acestea, aceste rate ar trebui validate în eşantioane mai mari şi se poate argumenta că sunt furnizate informaţii insuficiente despre cauzele prematurităţii sau ale mortalităţii neonatale pentru a trage concluzii certe. Pentru a consolida rezultatele (27), ar trebui efectuate studii generale de screening la nivel mondial şi studii de control potrivite.

Analizând prezentările de caz ale transmiterii verticale dovedite a virusului SARS-CoV-2, am constatat că, deşi majoritatea nou-născuţilor s-au născut prematuri, aceştia au fost prematuri tardivi (> 34 săptămâni GA) cu un scor APGAR şi greutate bune la naştere. Simptomele au fost foarte heterogene, cu trei 


\begin{tabular}{|c|c|c|c|c|}
\hline 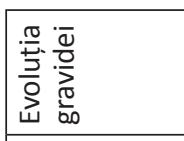 & 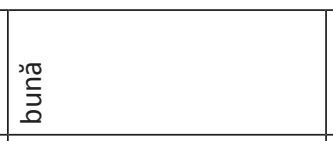 & 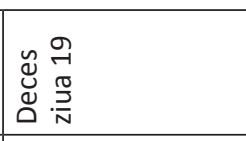 & 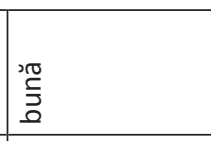 & 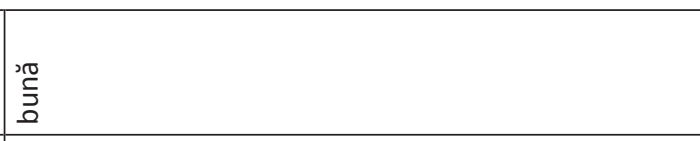 \\
\hline 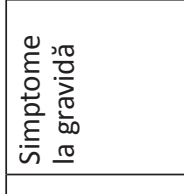 & 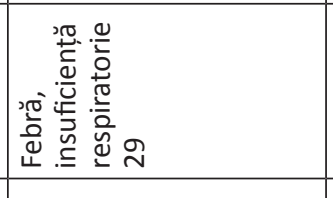 & 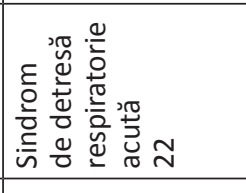 & 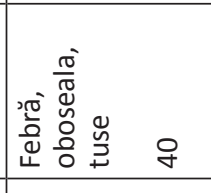 & 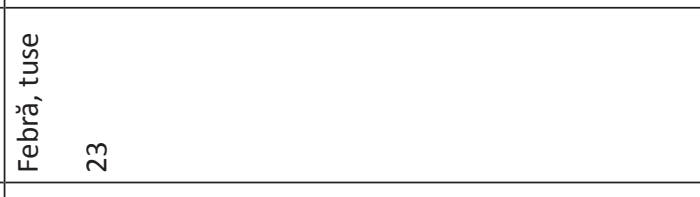 \\
\hline 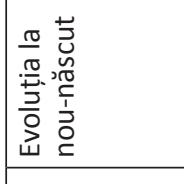 & 瓷 & 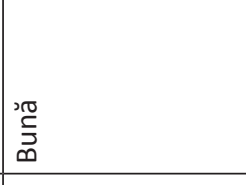 & 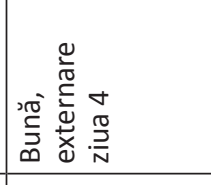 & 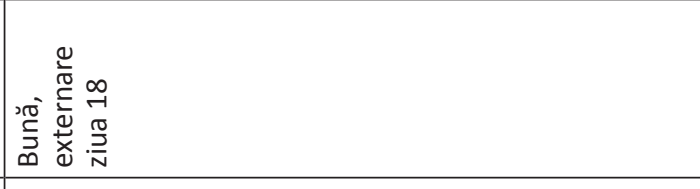 \\
\hline 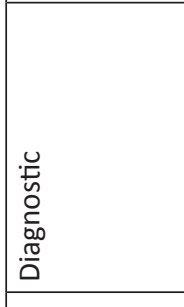 & 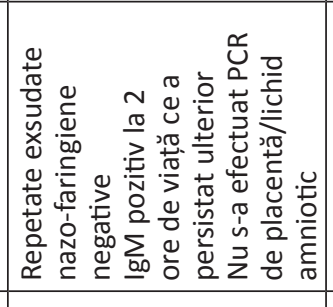 & 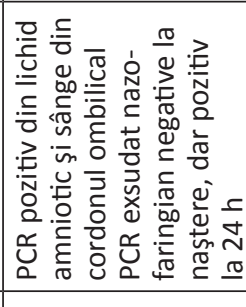 & 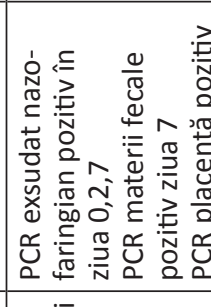 & 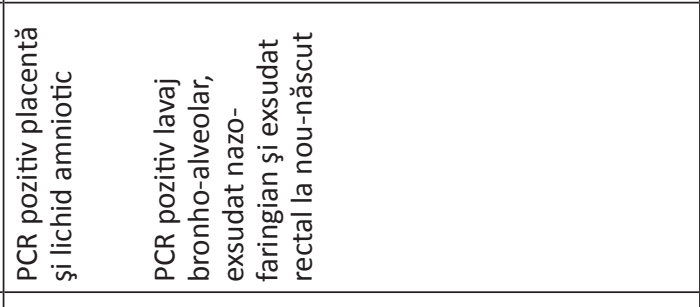 \\
\hline 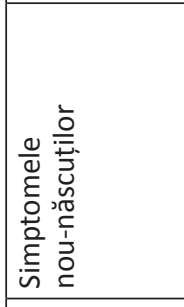 & 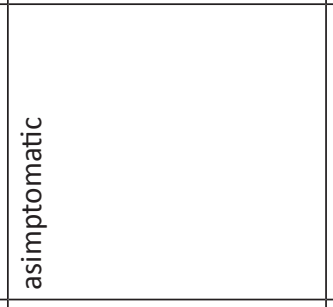 & 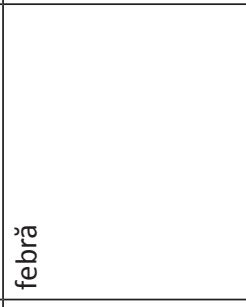 & 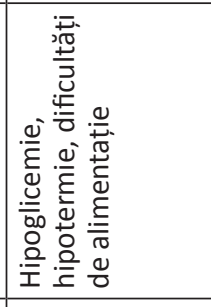 & 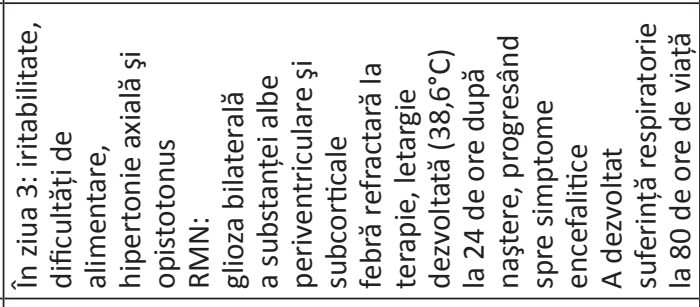 \\
\hline 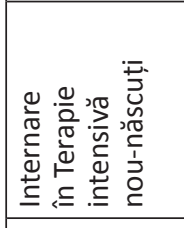 & 로 & 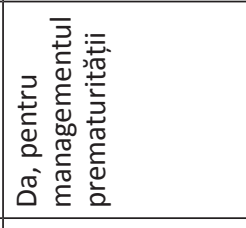 & 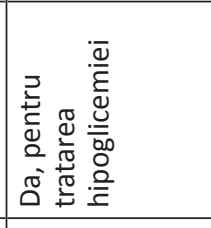 & 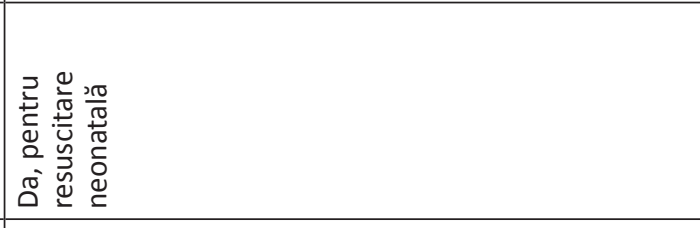 \\
\hline 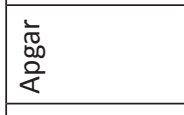 & $\begin{array}{l}0 \\
9 \\
0 \\
0\end{array}$ & $\begin{array}{l}\sigma \\
\infty \\
\infty\end{array}$ & $\begin{array}{l}\sigma \\
\sigma^{2}\end{array}$ & $\begin{array}{l}\mathcal{N} \\
\tilde{\sigma} \\
\end{array}$ \\
\hline 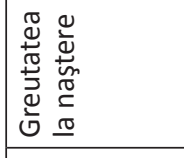 & 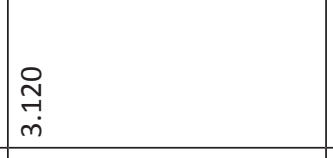 & 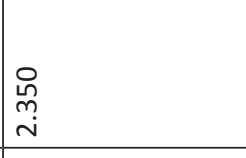 & 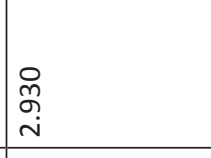 & $\begin{array}{l}\text { 导 } \\
\text { in } \\
\end{array}$ \\
\hline 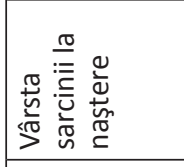 & 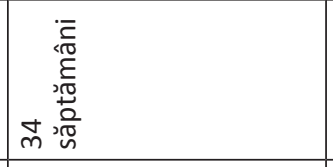 & 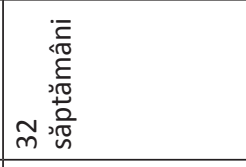 & 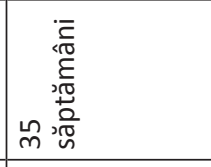 & 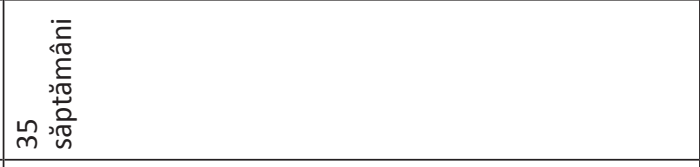 \\
\hline 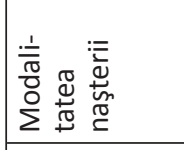 & 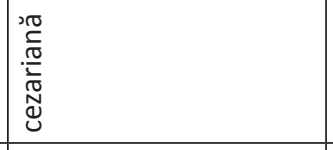 & 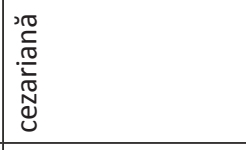 & 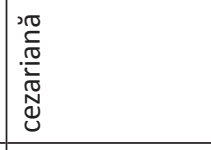 & 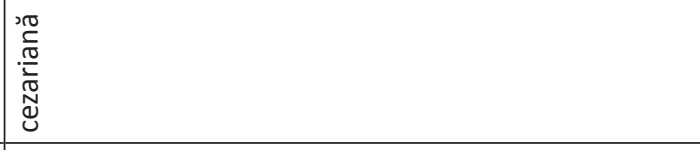 \\
\hline 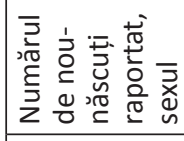 & $\underset{i}{\stackrel{4}{*}}$ & $\stackrel{4}{-1}$ & $\sum_{i}$ & $\sum_{i}$ \\
\hline 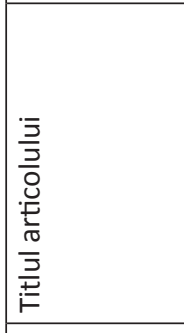 & 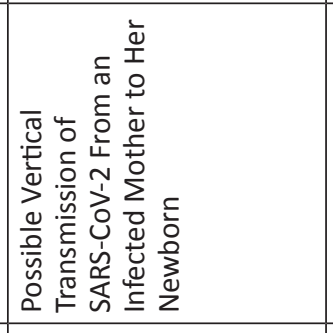 & 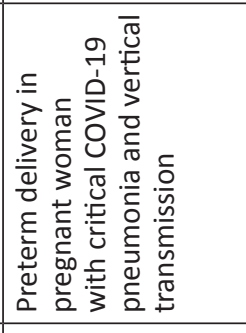 & 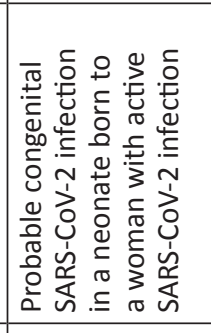 & 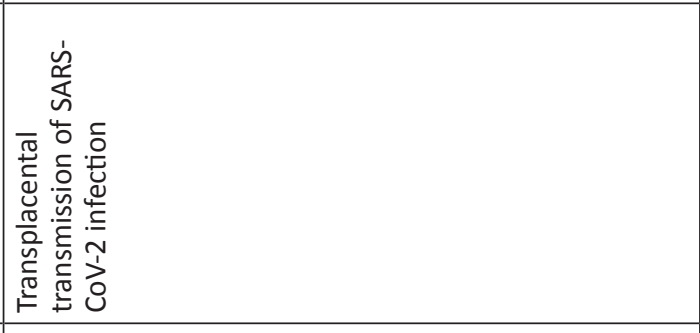 \\
\hline 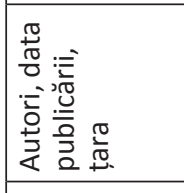 & 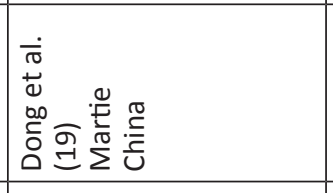 & 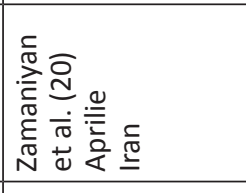 & 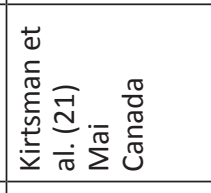 & 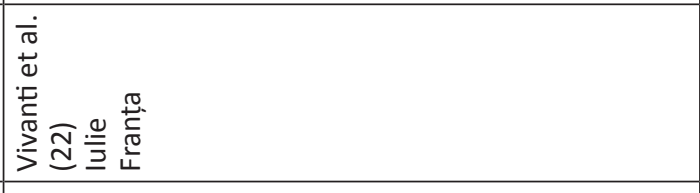 \\
\hline & 4 & N & m & + \\
\hline
\end{tabular}




\begin{tabular}{|c|c|c|c|}
\hline 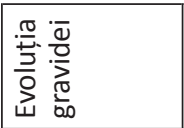 & 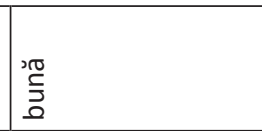 & $\begin{array}{l}20 \\
5 \\
5 \\
3\end{array}$ & 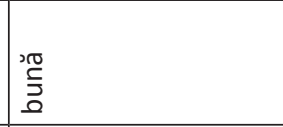 \\
\hline 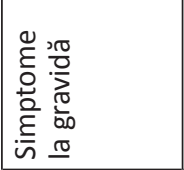 & 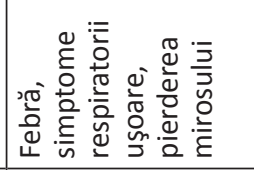 & 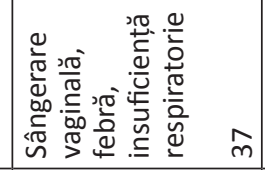 & 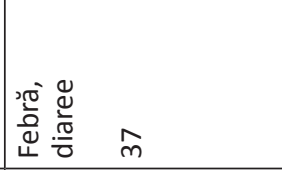 \\
\hline 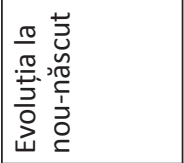 & 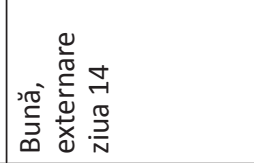 & 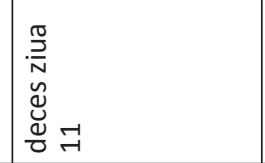 & 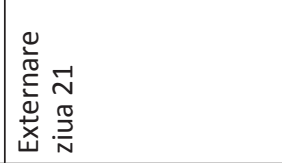 \\
\hline 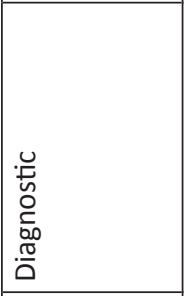 & 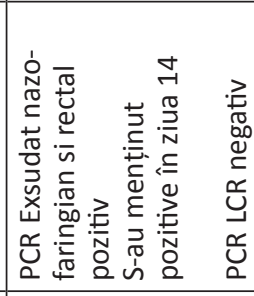 & 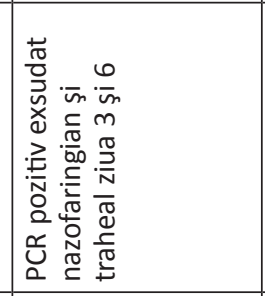 & 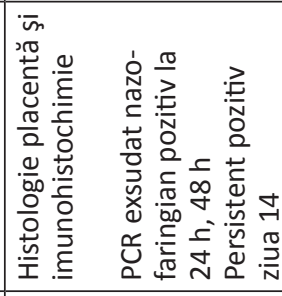 \\
\hline 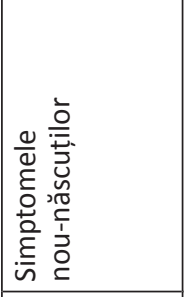 & & 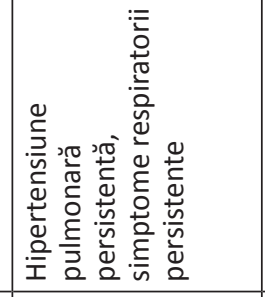 & 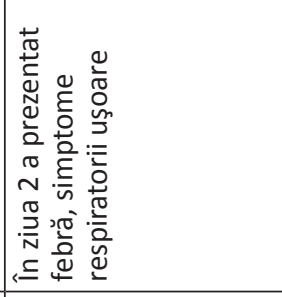 \\
\hline 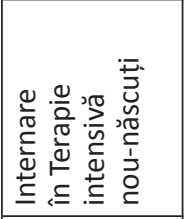 & 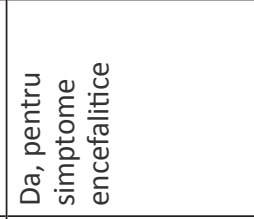 & 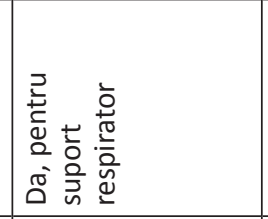 & 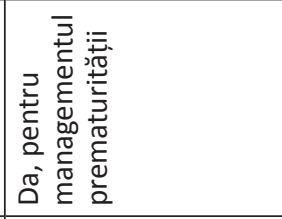 \\
\hline 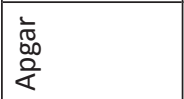 & $\begin{array}{l}\text { a } \\
\text { o. }\end{array}$ & $\begin{array}{l}\infty \\
\infty \\
\infty\end{array}$ & 品 \\
\hline 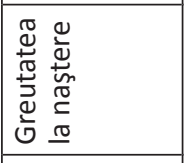 & 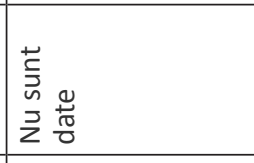 & 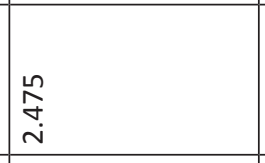 & $\begin{array}{l}\infty \\
\infty \\
\infty \\
\stackrel{n}{n} \\
\end{array}$ \\
\hline 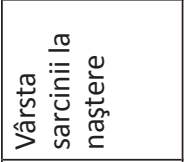 & 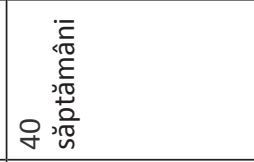 & 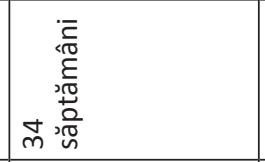 & 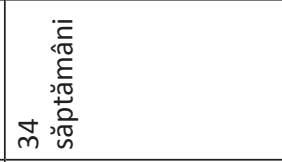 \\
\hline 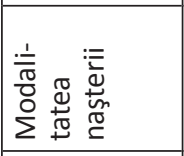 & 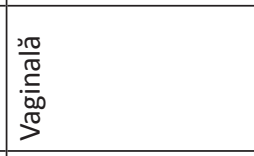 & 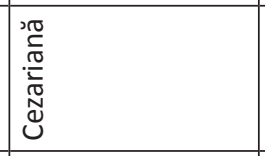 & $\begin{array}{l}\frac{2 \pi}{\pi} \\
. \frac{10}{60} \\
\frac{50}{2} \\
\end{array}$ \\
\hline 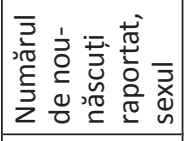 & $\stackrel{L}{u}$ & $\stackrel{u}{u}$ & $\stackrel{u}{\sim}$ \\
\hline 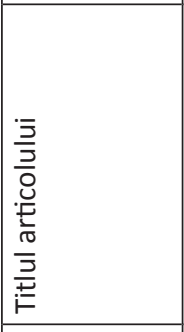 & 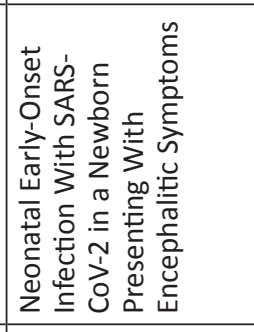 & 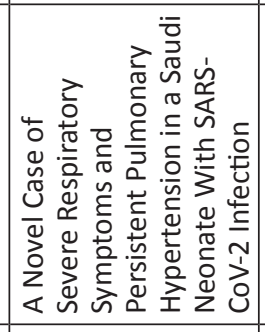 & 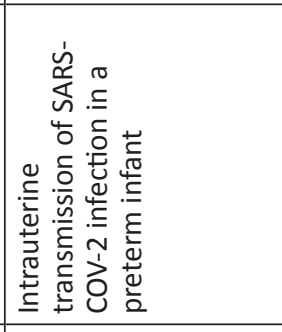 \\
\hline 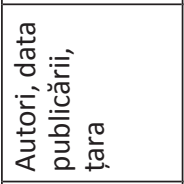 & 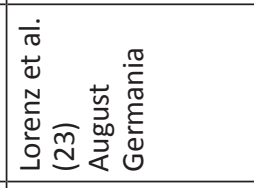 & 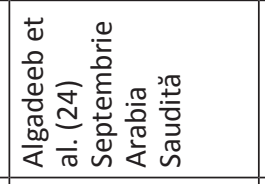 & 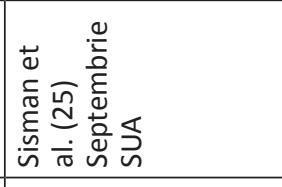 \\
\hline & in & & $r$ \\
\hline
\end{tabular}


nou-născuţi cu simptome uşoare (febră/simptome respiratorii minore) şi patru nou-născuţi care au simptome severe. Interesant este că doar un caz a prezentat o imagine respiratorie severă cu pneumonie şi hipertensiune pulmonară, care este prezentarea obişnuită pentru COVID-19 sever la adulţi. Într-un studiu realizat de Zhu şi colaboratorii (28), 6 din 10 sugari născuţi de mame COVID-19 pozitive au prezentat simptome respiratorii, deşi toate testele PCR au fost negative. Doi dintre nou-născuţi au prezentat simptome neurologice cu debut la mai mult de 24 de ore de viaţă şi dovezi imagistice de modificări cerebrale într-un caz.

În ceea ce priveşte evaluarea modalităţilor de diagnosticare a transmiterii in utero, am observat că, în funcţie de disponibilitatea testelor în fiecare centru, datele sunt variabile. Pentru majoritatea sugarilor descrişi în această revizuire, a fost demonstrată prezenţa virusului SARS-CoV-2 în placentă şi lichid amniotic, împreună cu izolare nazofaringienă de la nou-născuţi. Unul dintre studii a raportat modificări histologice prin colorarea specifică a citoplasmei pentru proteina nucleocapsidei SARS-CoV-2 prin imunohistochimie şi a demonstrat particule virale prin microscopie electronică în celulele sinciţiotrofoblastice, sugerând transmiterea intrauterină (25). În acest caz particular, femeia însărcinată a suferit ruperea prematură a membranelor, iar copilul s-a născut prin naştere vaginală. Prin urmare, transmiterea s-ar fi putut produce din cauza infecției ascendente şi a implicării primare a tractului gastro-intestinal matern sau a răspândirii hematogene în timpul viremiei cauzate de infecţia iniţială. Shanes şi colaboratorii au analizat 16 placente ale femeilor COVID-19 pozitive care au născut şi au găsit o rată crescută de malperfuzie vasculară maternă, cel mai proeminent arteriopatie deciduală, incluzând ateroză şi necroză fibrinoidă şi hipertrofie murală a arteriolelor cu membrană. Aceste modificări au fost asociate cu oligohidramnios, restricţie de creştere fetală, naştere prematură şi naştere de făt mort. $\mathrm{Cu}$ toate acestea, niciuna dintre placentele din studiul lui Shanes şi colab. nu a fost testată pentru SARS-CoV-2 ARN viral şi toţi sugarii au avut un test nazofaringian PCR negativ (29).

Patru din şapte cazuri din analiza noastră au prezentat PCR placentar, lichid amniotic şi exsudat nazo-faringian pozitiv la nou-născut. Un raport de caz publicat la începutul lunii martie 2020 nu a efectuat PCR de placentă/lichid amniotic, dar anticorpii IgM au fost pozitivi la 2 ore de viaţă şi pe mai multe probe repetate (19).
Evoluţia nou-născuţilor a fost bună, 6 din 7 s-au recuperat şi au fost externaţi în 3-21 de zile. A fost raportat un deces şi a fost, probabil, cauzat de simptomele respiratorii severe asociate cu hipertensiunea pulmonară. În acest caz, prematuritatea ar fi putut contribui la suferinţa respiratorie; cu toate acestea, contribuţia SARS-CoV-2 la patologia pulmonară prin receptorii enzimei 2 de conversie a angiotensinei este o opţiune plauzibilă.

Interesant este faptul că 4 din 7 femei gravide au prezentat simptome uşoare (febră, tuse sau diaree), în timp ce celelalte 3 au prezentat suferinţă respiratorie, una dintre ele asociând sângerări vaginale. Evoluţia şi rezultatul final au fost bune în 6 din 7 cazuri, mamele fiind externate acasă. Într-un caz a fost raportată o femeie însărcinată în vârstă de 22 de ani, care a prezentat deces prin insuficienţă respiratorie acută; acest eveniment a fost atribuit bolilor respiratorii severe care necesită ventilaţie şi, de asemenea, prezentării tardive la spital, în ziua a 4-a de simptome. World Association of Perinatal Medicine (30) a raportat o rată a mortalităţii de $0,4 \%$ la femeile însărcinate cu COVID-19, în timp ce Allotey şi colaboratorii (3) au constatat că creşterea vârstei materne, indicele ridicat de masă corporală şi comorbidităţile preexistente sunt factori de risc pentru infecţie COVID-19 severă la femeile gravide -condiţii similare riscului de boală severă la populaţia generală.

Transmiterea verticală este estimată la numai $3 \%$, iar aceasta este compatibilă cu datele recente, care raportează că celulele placentare care exprimă proteinele ACE2 şi TMPRSS2 necesare pentru intrarea celulelor SARS-CoV-2 sunt rare (31).

$\mathrm{Cu}$ toate acestea, mai multe întrebări rămân fără răspuns în acest moment, cum ar fi relaţia dintre boala COVID-19 severă în timpul sarcinii şi transmiterea verticală, efectele pe termen lung ale COVID-19 la nou-născuţi.

\section{Puncte tari și limitări}

În primul rând, analiza noastră abordează întrebări clinice şi de cercetare foarte importante, în timp ce există incertitudini în ceea ce priveşte efectele materne şi neonatale ale sarcinii la femeile cu COVID-19. Totodată, studiul nostru aduce informaţii despre transmisia verticală şi care sunt efectele acesteia.

Recunoaştem că în acest moment lumea ştiinţifică şi medicală doreşte să afle mai multe despre efectul 
COVID-19 cât mai curând posibil pentru a preveni şi a se pregăti pentru consecinţe grave. Având în vedere acest lucru, multe lucrări sunt publicate rapid şi unele ar putea multiplica informaţiile sau să interpreteze greşit datele. Prin urmare, analiza noastră urmăreşte rezumarea şi analiza datelor fiabile din studiile de calitate, incluzând doar cazuri confirmate de laborator pentru a oferi răspunsuri fiabile.

O limitare este că nu toate studiile au evaluat aceleaşi variabile, prin urmare unele rezultate se vor baza pe un număr limitat de raportări.

Conflict of interest: none declared

Financial support: none declared

\section{BIBLIOGRAFIE}

1. World Health Organization. Coronavirus disease (COVID-2019) situation reports. Available at: https://www.who.int/publications/m/ item/weekly-epidemiological-update - 17-november-2020.

2. Sedgh G, Singh S, Hussain R. Intended and unintended pregnancies worldwide in 2012 and recent trends. Stud Fam Plann. 2014;45(3):301-314

3. Allotey J, Stallings $\mathrm{E}$, Bonet $\mathrm{M}$, et al. Clinical manifestations, risk factors, and maternal and perinatal outcomes of coronavirus disease 2019 in pregnancy: living systematic review and metaanalysis. BMJ. 2020 Sep 1;370:m3320

4. Egloff C, Vauloup-Fellous $\mathrm{C}$, Picone $\mathrm{O}$, et al. Evidence and possible mechanisms of rare maternal-fetal transmission of SARS-CoV-2. J Clin Virol. 2020 Jul;128:104447.

5. Shalish W, Lakshminrusimha S, Manzoni P, et al. COVID-19 and Neonatal Respiratory Care: Current Evidence and Practical Approach. Am J Perinatol. 2020 Jun;37(8):780-791.

6. Elshafeey $F$, Magdi $R$, Hindi $N$, et al. A systematic scoping review of COVID-19 during pregnancy and childbirth. Int J Gynaecol Obstet. 2020 Jul;150(1):47-52.

7. Lamouroux A, Attie-Bitach T, Martinovic J et al. Evidence for and against vertical transmission for severe acute respiratory syndrome coronavirus 2. Am J Obstet Gynecol. 2020 Jul;223(1):91.e1-91.e4.

8. Sheth S, Shah N, Bhandari V. Outcomes in COVID-19 Positive Neonates and Possibility of Viral Vertical Transmission: A Narrative Review. Am J Perinatol. 2020 Oct;37(12):1208-1216.

9. Dhir SK, Kumar J, Meena J, et al. Clinical Features and Outcome of SARS-CoV-2 Infection in Neonates: A Systematic Review. J Trop Pediatr. 2020 Aug 28:fmaa059.

10. Ghayda RA, Li H, Lee KH, et al. COVID-19 and Adverse Pregnancy Outcome: A Systematic Review of 104 Cases. J Clin Med. 2020 Oct 26;9(11):E3441.

11. Yee J, Kim W, Han JM, et al. Clinical manifestations and perinatal outcomes of pregnant women with COVID-19: a systematic review and meta-analysis. Sci Rep. 2020 Oct 22;10(1):18126.

12. Huntley BJF, Huntley ES, Di Mascio D, et al. Rates of Maternal and Perinatal Mortality and Vertical Transmission in Pregnancies Complicated by Severe Acute Respiratory Syndrome Coronavirus 2 (SARS-Co-V-2) Infection: A Systematic Review. Obstet Gynecol. 2020 Aug;136(2):303-312.

13. Zaigham $M$, Andersson $O$. Maternal and perinatal outcomes with COVID-19: A systematic review of 108 pregnancies. Acta Obstet Gynecol Scand. 2020 Jul;99(7):823-829.

14. Pettirosso E, Giles M, Cole S, et al. COVID-19 and pregnancy: A review of clinical characteristics, obstetric outcomes and vertical transmission. Aust N Z J Obstet Gynaecol. 2020 Oct;60(5):640-659.

15. Di Toro F, Gjoka M, Di Lorenzo G, et al. Impact of COVID-19 on maternal and neonatal outcomes: a systematic review and meta-analysis. Clin Microbiol Infect. 2020 Nov 1:S1198743X(20)30618-2.

16. Kotlyar AM, Grechukhina O, Chen A, et al. Vertical transmission of coronavirus disease 2019: a systematic review and meta-analysis. Am J Obstet Gynecol. 2020 Jul 31:S0002-9378(20)30823-1.

\section{CONCLUZII}

Impactul infecţiei COVID-19 asupra rezultatului sarcinii este similar cu populaţia generală în ceea ce priveşte rata prematurităţii şi rata mortalităţii. Transmiterea verticală este posibilă şi pare să aibă loc în aproximativ 3\% dintre cazuri. Prognosticul general matern şi perinatal este favorabil, iar prezentarea clinică a transmiterii verticale a SARS-CoV-2 la nounăscuţi este heterogenă.
17. Vardhelli V, Pandita A, Pillai A, et al. Perinatal COVID-19: review of current evidence and practical approach towards prevention and management. Eur J Pediatr. 2020 Nov 12:1-23.

18. Di Mascio D, Khalil A, Saccone G, et al. Outcome of coronavirus spectrum infections (SARS, MERS, COVID-19) during pregnancy: a systematic review and meta-analysis. Am J Obstet Gynecol MFM. 2020 May;2(2):100107.

19. Dong L, Tian J, He S, et al. Possible Vertical Transmission of SARS-CoV-2 From an Infected Mother to Her Newborn. JAMA. 2020 May 12;323(18):1846-1848.

20. Zamaniyan M, Ebadi A, Aghajanpoor S, et al. Preterm delivery, maternal death, and vertical transmission in a pregnant woman with COVID-19 infection. Prenat Diagn. 2020;40(13):1759-1761.

21. Kirtsman M, Diambomba $Y$, Poutanen SM, et al. Probable congenital SARS-CoV-2 infection in a neonate born to a woman with active SARS-CoV-2 infection. CMAJ. 2020 Jun 15;192(24):E647-E650.

22. Vivanti AJ, Vauloup-Fellous $C$, Prevot $S$, et al. Transplacental transmission of SARS-CoV-2 infection. Nat Commun. $2020 \mathrm{Jul}$ 14;11(1):3572.

23. Lorenz N, Treptow A, Schmidt S, et al. Neonatal Early-Onset Infection With SARS-CoV-2 in a Newborn Presenting With Encephalitic Symptoms. Pediatr Infect Dis J. 2020 Aug;39(8):e212.

24. Algadeeb KB, AlMousa HH, AlKadhem SM, et al. A Novel Case of Severe Respiratory Symptoms and Persistent Pulmonary Hypertension in a Saudi Neonate With SARS-CoV-2 Infection. Cureus. 2020 Sep 15;12(9):e10472.

25. Sisman J, Jaleel MA, Moreno W, et al. Intrauterine Transmission of SARS-COV-2 Infection in a Preterm Infant. Pediatr Infect Dis J. 2020 Sep;39(9):e265-e267.

26. WHO.int [homepage on the internet]. Preterm birth. Geneva, WHO, 2018, [accessed 20 November 2020]. Available at:https://www.who. int/news-room/fact-sheets/detail/preterm-birth.

27. WHO.int [homepage on the internet]. Stillbirth birth. Geneva, WHO, 2018, [accessed 20 November 2020]. Available at: https://www.who. int/reproductivehealth/topics/maternal_perinatal/stillbirth/en/.

28. Zhu $\mathrm{H}$, Wang $\mathrm{L}$, Fang $\mathrm{C}$, et al. Clinical analysis of 10 neonates born to mothers with 2019-nCoV pneumonia. Transl Pediatr. 2020;9(1):51-60.

29. Shanes DE, Mithal LB, Otero $S$ et al. Placental pathology in COVID-19. Am J Clin Pathol. 2020 Jun;154(1):23-32.

30. WAPM (World Association of Perinatal Medicine) Working Group on COVID-19. Maternal and perinatal outcomes of pregnant women with SARS-CoV-2 infection. Ultrasound Obstet Gynecol. 2020 Sep 14.

31. Pique-Regi R, Romero R, Tarca A, et al. Does the human placenta express the canonical cell entry mediators for SARS-CoV-2? Elife 2020:9:e58716. 